\title{
Epigonus merleni, a Junior Synonym of Epigonus macrops (Actinopterygii: Perciformes: Epigonidae)
}

\author{
Makoto Okamoto ${ }^{1,4}$, Peter Bartsch ${ }^{2}$ and Hiroyuki Motomura ${ }^{3}$ \\ ${ }^{1}$ Seikai National Fisheries Research Institute, 1551-8 Taira-machi, Nagasaki 851-2213, Japan \\ E-mail: okamako@affrc.go.jp \\ ${ }^{2}$ Museum für Naturkunde, Leibniz Institute for Research on Evolution and Biodiversity, Humboldt University Berlin, \\ Invalidenstr. 43, D-10115 Berlin, Germany \\ ${ }^{3}$ The Kagoshima University Museum, 1-21-30 Korimoto, Kagoshima 890-0065, Japan \\ ${ }^{4}$ Corresponding author
}

(Received 4 July 2012; Accepted 4 September 2012)

\begin{abstract}
Epigonus merleni McCosker and Long, 1997 was originally described on the basis of a single specimen collected from the Galápagos Islands. It was considered to be distinguished from E. macrops (Brauer, 1906) by having $11+14$ vertebrae and 57 lateral-line scales, but our examination of the holotype of E. merleni revealed that it actually has $10+15$ vertebrae and $48+5$ lateral-line scales. The holotype also has a luminescent window near the pelvic-fin base that is otherwise unique to E. macrops in the genus. Based on our comparison of the holotype of E. merleni with a syntype and other specimens of $E$. macrops, we conclude that E. merleni is a junior synonym of E. macrops.
\end{abstract}

Key Words: Teleostei, deepwater cardinalfish, Epigonus, synonymy.

\section{Introduction}

Epigonus merleni McCosker and Long, 1997 was originally described from a single specimen collected on the sea surface during the 1995 eruption of Fernandina Volcano in the Galápagos Islands. According to McCosker and Long (1997), this species belongs to the "E. telescopus group" (sensu Abramov 1992) in having eight spines on the first dorsal fin. McCosker and Long (1997) distinguished their new species from the other four species of the group by its five pyloric caeca, 17 pectoral-fin rays, nine soft rays in the second dorsal fin, and $11+14$ vertebrae. Our examination of the type specimen of E. merleni revealed that the original description did not accurately report several important characters. Comparison with other congeners has subsequently led us to conclude that E. merleni is a junior synonym of Epigonus macrops (Brauer, 1906).

\section{Materials and Methods}

Methods for enumerating meristic and morphometric characters follow Mayer (1974) except for body depth and body width, for which we follow the definitions of Okamoto (2011). Missing lateral-line scales were estimated by counting scale pockets. The number of pored lateral-line scales on the caudal fin is represented as " $+n$ ". Definition of the first caudal vertebra follows Okamoto and Motomura (2011). Counts of vertebrae and ribs were taken from radiographs. The presence of a ventral luminescent window, the number of pyloric caeca, and sex were established by dissection of the abdomen on the right side. Standard length is abbreviated as SL. Institutional abbreviations for the depositories of the examined specimens are: AMS, Australian Museum, Sydney; CAS, California Academy of Sciences, San Francisco; HUMZ, Hokkaido University Museum, Hakodate; MCZ, Museum of Comparative Zoology, Harvard University, Cambridge; NSMT, National Museum of Nature and Science, Tsukuba; TCWC, Texas A\&M University, College Station, Texas; USNM, Smithsonian Institution National Museum of Natural History, Suitland; and ZMB, Ichthyology, Zoologisches Museum, Museum für Naturkunde, Berlin.

Material examined. Epigonus macrops (13 specimens): ZMB 17678 , syntype, $202.5 \mathrm{~mm} \mathrm{SL}, 03^{\circ} 22^{\prime} 01^{\prime \prime}$, $101^{\circ} 11^{\prime} 05^{\prime \prime} \mathrm{E}$, western coast of Sumatra, Indonesia, eastern Indian Ocean, $903 \mathrm{~m}$ depth, 21 January 1899; CAS 86581, holotype of E. merleni, $139.1 \mathrm{~mm} \mathrm{SL}, 00^{\circ} 28^{\prime} \mathrm{S}, 91^{\circ} 37^{\prime} \mathrm{W}$, surface offshore of Cabo Hammond, Isla Fernandina, Galápagos Islands, eastern Pacific, February 1995; AMS I. 22814$018,131.6 \mathrm{~mm} \mathrm{SL}, 18^{\circ} 48^{\prime} 00^{\prime \prime} \mathrm{S}, 116^{\circ} 60^{\prime} 00^{\prime \prime} \mathrm{E}$, northwest of Port Headland, Australia, Indian Ocean, $704 \mathrm{~m}$ depth, 6 April 1982; AMS I. 31161-004, 170.5 mm SL, 245' 67"S, $111^{\circ} 80^{\prime} 83^{\prime \prime} \mathrm{E}$, off Cape Cuvier, Australia, Indian Ocean, $901 \mathrm{~m}$ depth, 28 January 1991; CSIRO H 2562-01, $178.4 \mathrm{~mm}$ SL, $24^{\circ} 28^{\prime} \mathrm{S}, 111^{\circ} 51^{\prime} \mathrm{E}$, west of Quobba Point, Australia, Indian Ocean, $905 \mathrm{~m}$ depth, 28 January 1991; CSIRO H 6575$08,126.8 \mathrm{~mm} \mathrm{SL}, 14^{\circ} 35^{\prime} \mathrm{S}, 121^{\circ} 21^{\prime} \mathrm{E}$, northwest of Cape Leveque, Australia, Indian Ocean, $709 \mathrm{~m}$ depth, 26 June 2007; MCZ 48827, $148.7 \mathrm{~mm} \mathrm{SL}, 11^{\circ} 54^{\prime} \mathrm{N}, 69^{\circ} 18^{\prime} \mathrm{W}$, Caribbean Sea, $910 \mathrm{~m}$ depth, 4 October 1963; TCWC 6372.09, 4 specimens, $103.7-145.6 \mathrm{~mm}$ SL, $27^{\circ} 64^{\prime} \mathrm{N}, 91^{\circ} 53^{\prime} \mathrm{W}$, Gulf of Mexico, $731 \mathrm{~m}$ depth, 3 March 1986; TCWC 7003.10, 2 specimens $120.6-156.7 \mathrm{~mm} \mathrm{SL}, 27^{\circ} 14^{\prime} \mathrm{N}, 93^{\circ} 39^{\prime} \mathrm{W}$, Gulf of Mexico, 792-864 m depth, 8 April 1986.

Comparative materials. Epigonus angustifrons 

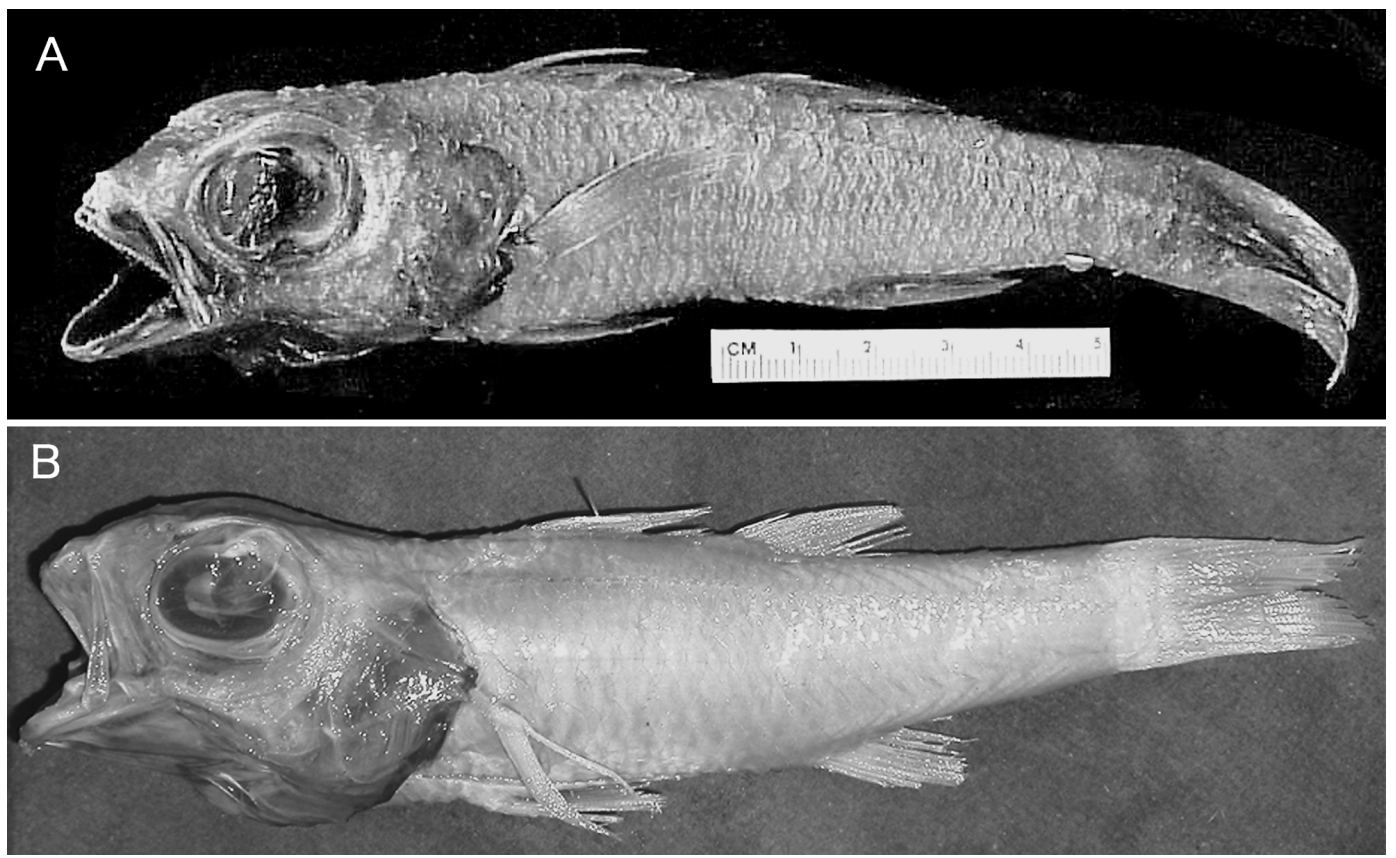

Fig. 1. Photographs of Epigonus macrops. A, holotype of E. merleni (CAS 86581, 139.1 mm SL); B, syntype of E. macrops (ZMB 17678, $202.5 \mathrm{~mm} \mathrm{SL}$ ).
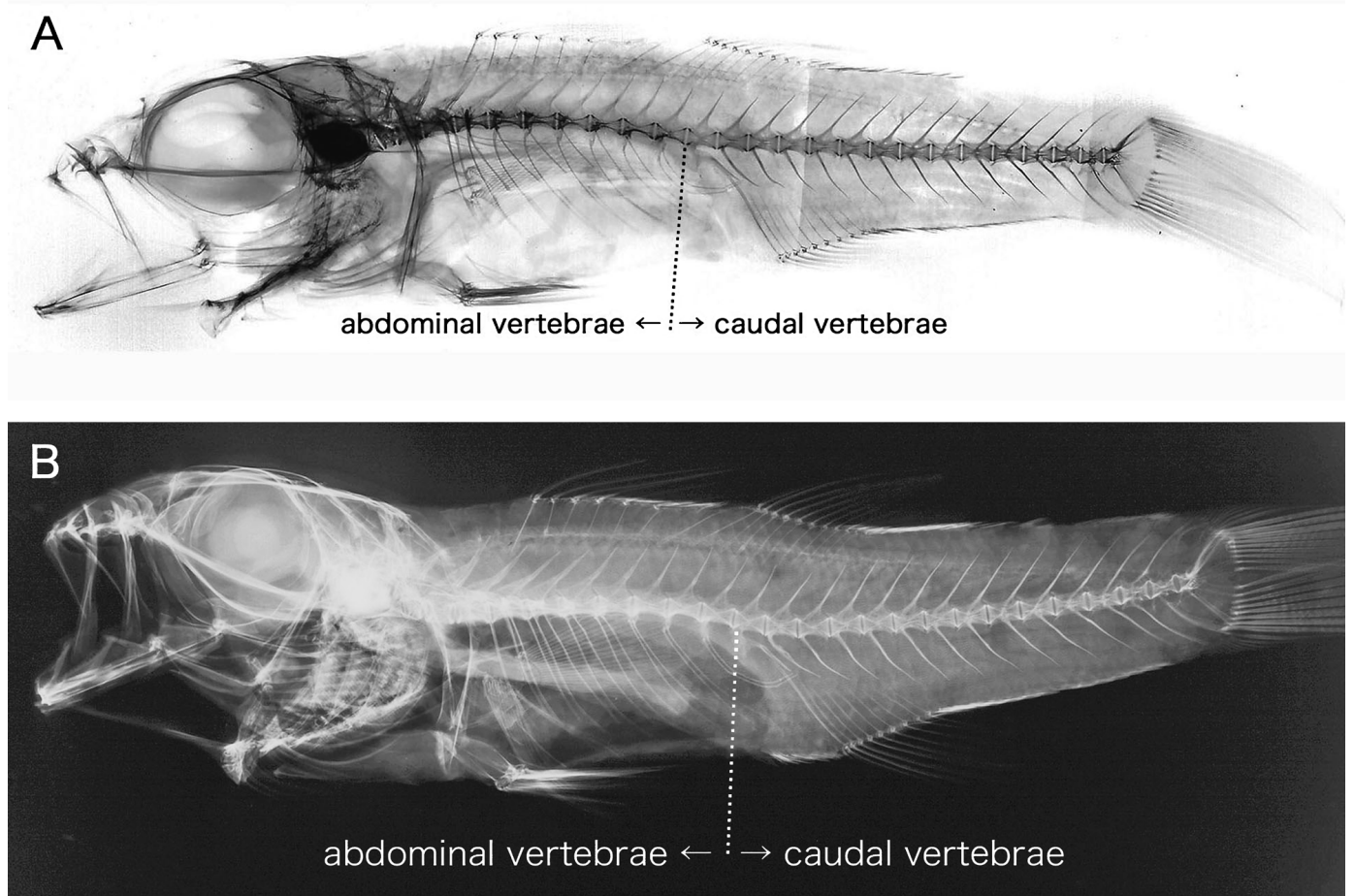

Fig. 2. X-ray photographs of Epigonus macrops. A, holotype of E. merleni (CAS 86581, 139.1 mm SL); B, syntype of E. macrops (ZMB $17678,202.5 \mathrm{~mm} \mathrm{SL})$.

Abramov and Manilo, 1987: HUMZ 99978, $216.0 \mathrm{~mm}$ SL, $26^{\circ} 09^{\prime} \mathrm{S}, 06^{\circ} 21^{\prime} \mathrm{E}$, eastern South Atlantic, $246 \mathrm{~m}$ depth, 10 March 1983. Epigonus notacanthus Parin and Abramov, 1986: HUMZ 166513, $107.6 \mathrm{~mm} \mathrm{SL}, 25^{\circ} 33^{\prime} \mathrm{S}, 87^{\circ} 15^{\prime} \mathrm{W}$, Nazca Ridge, eastern South Pacific, 11 October 1999; HUMZ 166519, $90.7 \mathrm{~mm}$ SL, data same as HUMZ 166513. Epigonus telescopus (Risso, 1810): AMS I. 28165-001, 3 specimens, 112.4-187.9 mm SL, $33^{\circ} 35^{\prime} 17^{\prime \prime} \mathrm{S}, 44^{\circ} 09^{\prime} 33^{\prime \prime}$ E, Walters Shoal, southwestern Indian Ocean, $750 \mathrm{~m}$ depth, 18 December 1988; USNM 307603, $201.2 \mathrm{~mm} \mathrm{SL}, 33^{\circ} 43^{\prime} 42^{\prime \prime} \mathrm{S}, 43^{\circ} 61^{\prime} 58^{\prime \prime} \mathrm{E}$, Walters Shoal, southwestern Indian Ocean, 1,000-1,030 m depth, 17 December 1988; USNM 307608, 2 specimens, $137.8-154.3 \mathrm{~mm} \mathrm{SL}, 33^{\circ} 37^{\prime} 42^{\prime \prime} \mathrm{S}, 44^{\circ} 10^{\prime} 42^{\prime \prime} \mathrm{E}$, Walters Shoal, southwestern Indian Ocean, 750-775 m depth, 18 December 1988. 
Table 1. Selected counts and measurements of specimens of Epigonus macrops, including the holotype of E. merleni and a syntype of E. macrops.

\begin{tabular}{|c|c|c|c|}
\hline & \multirow{3}{*}{$\begin{array}{l}\text { E. merleni } \\
\text { CAS } 86581 \\
\text { Holotype }\end{array}$} & \multicolumn{2}{|c|}{ E. macrops } \\
\hline & & ZMB 17678 & Other specimens \\
\hline & & Syntype & $n=11$ \\
\hline Standard length (mm) & 139.1 & 202.5 & $103.7-178.4$ \\
\hline \multicolumn{4}{|l|}{ Counts } \\
\hline Dorsal-fin rays & VII-I-I, 10 & VII-I-I, 10 & VII-I-I, 10 \\
\hline Anal-fin rays & II, 9 & II, 9 & II, 9 \\
\hline Pelvic-fin rays & 19 & 18 & $18-19$ \\
\hline Pored lateral-line scales & $48+5$ & $51+5$ & $44-51+2-5$ \\
\hline Gill rakers & $4+15=19$ & $4+15=19$ & $4-5+13-15=18-20$ \\
\hline Vertebrae & $10+15$ & $10+15$ & $10+15$ \\
\hline \multicolumn{4}{|l|}{ Measurements (\% standard length) } \\
\hline Head length & 36.7 & 37.8 & $34.6-37.8$ \\
\hline Head height & 18.6 & 17.8 & $17.4-20.2$ \\
\hline Body depth & 24.2 & 23.2 & $20.8-24.3$ \\
\hline Body width & 17.3 & 17.7 & $14.0-17.7$ \\
\hline Caudal-peduncle depth & 10.4 & 10.7 & $8.9-10.9$ \\
\hline Caudal-peduncle length & 26.1 & 24.5 & $24.4-28.9$ \\
\hline Orbital diameter & 15.3 & 14.3 & $12.7-17.5$ \\
\hline Interorbital width & 10.9 & 12.0 & $10.2-11.5$ \\
\hline Postorbital length & 14.2 & 14.4 & $12.3-14.6$ \\
\hline Upper-jaw length & 14.0 & 14.3 & $13.3-14.8$ \\
\hline Lower-jaw length & 17.3 & 17.0 & $15.9-19.3$ \\
\hline Snout length & 7.9 & 9.4 & $6.7-9.5$ \\
\hline Pre-1st dorsal-fin length & 36.9 & 40.0 & $36.8-40.1$ \\
\hline Pre-2nd dorsal-fin length & 57.3 & 60.1 & $57.0-60.3$ \\
\hline Pre-pectoral-fin length & 35.5 & 39.3 & $35.2-39.5$ \\
\hline Pre-pelvic-fin length & 36.0 & 41.6 & $35.8-41.7$ \\
\hline Pre-anus length & 59.0 & 61.4 & $57.0-61.7$ \\
\hline Pre-anal-fin length & 64.4 & 68.3 & $64.3-69.4$ \\
\hline 1st spine length on 1st dorsal fin & 2.2 & Tip broken & $1.2-2.8$ \\
\hline 2nd spine length on 1st dorsal fin & 12.4 & 14.1 & $11.5-15.9$ \\
\hline 3rd spine length on 1st dorsal fin & 14.1 & 14.5 & $12.3-15.7$ \\
\hline 2nd dorsal-fin spine length & 7.5 & 6.0 & $4.9-7.8$ \\
\hline 1 st anal-fin spine length & 1.4 & Tip broken & $1.2-2.7$ \\
\hline 2nd anal-fin spine length & 7.6 & 7.7 & $4.8-8.8$ \\
\hline Pelvic-fin spine length & 13.5 & 13.5 & $11.7-14.8$ \\
\hline 1st dorsal-fin base & 14.3 & 11.5 & $10.8-16.0$ \\
\hline 2nd dorsal-fin base & 10.6 & 9.8 & $9.6-11.3$ \\
\hline Anal-fin base & 9.3 & 9.7 & $9.3-10.9$ \\
\hline Pectoral-fin length & 21.2 & 20.7 & $16.7-21.3$ \\
\hline Pelvic-fin length & 15.8 & 15.7 & $14.9-16.0$ \\
\hline
\end{tabular}

\section{Results and Discussion}

McCosker and Long (1997) referred E. merleni to the E. telescopus group (sensu Abramov 1992) based on the presence of eight spines in the first dorsal fin. According to Abramov (1992) and Okamoto (2012), this species group comprises four species besides E. merleni: E. angustifrons, E. macrops, E. notacanthus, and E. telescopus. McCosker and Long (1997) stated that E. merleni is distinguishable from three species of this group in having $11+14$ vertebrae (the same number as in E. telescopus vs $10+15$ vertebrae in $E$. angustifrons, E. macrops, and E. notacanthus); however, our examination of the holotype of E. merleni revealed the vertebral number to be $10+15$ (Fig. 2). There are no clear differences in other meristic and morphometric characters between this holotype and the examined specimens, including a syntype of E. macrops (Table 1). In addition, we confirmed the presence of a luminescent window near the pelvic-fin base in the holotype of E. merleni (Fig. 3). Mayer (1974) considered a ventral luminescent organ to be unique for $E$. macrops within the genus. Accordingly, the holotype of $E$. merleni is considered to be a specimen of E. macrops, and the former nominal species is reduced to a junior synonym of E. macrops.

In addition to the above-mentioned characters, the 

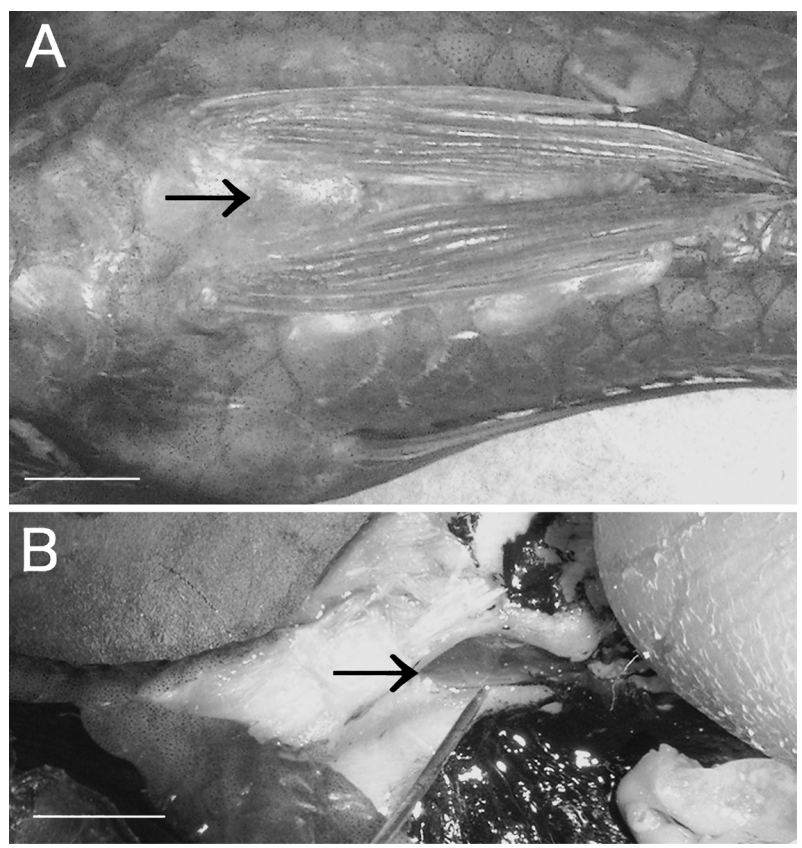

Fig. 3. External (A) and internal (B) views of the ventral region of the holotype of Epigonus merleni (CAS 86581, $139.1 \mathrm{~mm} \mathrm{SL}$ ). Arrows point to the luminescent window, covering a large scale in A. Scale bars: $5 \mathrm{~mm}$.

dorsal- and anal-fin ray counts and the number of lateral-line scales reported by McCosker and Long (1997) for E. merleni are erroneous. Although these authors presented the count as "dorsal rays VIII+I, 9", the holotype of $E$. merleni has seven spines in the first dorsal fin, an isolated spine between the first and second dorsal fins, and one spine and ten soft rays in the second dorsal fin (expressed as VII-I-I, 10). Our examination of the other species of the E. telescopus group showed that the first dorsal fin of all species comprises seven spines connected by a fin membrane, plus an eighth isolated spine. A number of authors (e.g., Mayer 1974; Abramov and Manilo 1987; Abramov 1992) have misconstrued the condition of the first dorsal fin and given the spine count as VIII. Abramov (1992) considered that count a unique diagnostic character for the E. telescopus group. McCosker and Long (1997) also stated that the anal fin has one spine rather than two as in other species of Epigonus. We confirmed there are two spines in the anal fin of the holotype of E. merleni. Although McCosker and Long (1997) described E. merleni as having the greatest number of pored lateral-line scales (57) in the genus, in the holotype we found only 48 pored lateral-line scales to the end of the hypural, plus 5 pored lateral-line scales on the caudal fin.

\section{Acknowledgments}

We are especially grateful to T. Iwamoto (CAS) for providing valuable data on the holotype of E. merleni and for his critical reading of this manuscript. We also thank $\mathrm{M}$. McGrouther (AMS), A. Graham (CSIRO), M. Yabe and T. Kawai (HUMZ), K. Hartel (MCZ), K. W. Conway and H. L. Prestridge (TCWC), and J. Williams and E. Wilbur (USNM) for loans of comparative specimens.

\section{References}

Abramov, A. A. 1992. Species composition and distribution of Epigonus (Epigonidae) in the world ocean. Journal of Ichthyology 32: 94-108.

Abramov, A. A. and Manilo, L. G. 1987. Epigonus angustifrons sp. n., a new cardinal fish (Perciformes, Apogonidae) from submarine mountain ridges in the subtropical zone of the Indian Ocean. Byulleten Moskovskogo Obshchestva Ispytatelei Prirody. Otdel Biologicheskii 92: 45-48. [In Russian]

Mayer, G. F. 1974. A revision of the cardinalfish genus Epigonus (Perciformes, Apogonidae), with descriptions of two new species. Bulletin of the Museum of Comparative Zoology 146: 147-203.

McCosker, J. E. and Long, D. J. 1997. A new species of the deepwater cardinalfish Epigonus (Perciformes: Epigonidae) from the Galápagos Islands. Ichthyological Research 44: 125-129.

Okamoto, M. 2011. A new species of deepwater cardinalfish, Epigonus mayeri, from the eastern Central Atlantic, and redescription of Epigonus heracleus Parin and Abramov 1986 (Perciformes: Epigonidae). Ichthyological Research 58: 101-108.

Okamoto, M. 2012. Two new species of the genus Epigonus (Perciformes: Epigonidae) from the South Pacific, with a definition of the Epigonus constanciae group. Ichthyological Research 59: 252254.

Okamoto, M. and Motomura, H. 2011. Epigonus carbonarius, a new species of deepwater cardinalfish (Perciformes: Epigonidae) from the Marquesas Islands, with a redefinition of the Epigonus oligolepis group. Ichthyological Research 58: 155-160. 